\title{
Numerical modeling of dynamics of Russian south waters within the framework of operational oceanography tasks
}

A. V. Grigoriev ${ }^{1}$, A. G. Zatsepin ${ }^{2}$, V. A. Kubryakov ${ }^{1}$, I. V. Charikov ${ }^{1}$, and L. D. Fedotova ${ }^{1}$

${ }^{1}$ N. N. Zubov's State Oceanographic Institute, Moscow, Russian Federation

${ }^{2}$ Shirshov's Institute of Oceanology, Moscow, Russian Federation

Received: 17 December 2010 - Accepted: 30 June 2011 - Published: 29 August 2011

Correspondence to: A. V. Grigoriev (ag-privat@mail.ru)

Published by Copernicus Publications on behalf of the European Geosciences Union.

Numerical modeling of dynamics of

Russian south waters

A. V. Grigoriev et al.

\section{Title Page}

Abstract

Introduction

Conclusions

References

Tables

Figures

14

$\checkmark$

Back

Close

\section{Full Screen / Esc}

Printer-friendly Version

Interactive Discussion

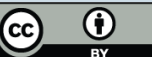




\section{Abstract}

Modeling of the Black Sea and Caspian Sea waters dynamics was conducted within the framework of the European ECOOP project and Russian project JISWO on the basis of the Princeton Ocean Model (POM). Nowcasting and tree days forecasting of the Black

5 Sea dynamics was carried out in a daily mode with horizontal resolution of $\sim 1 \mathrm{~km}$ along the Russian coast of the basin. The nowcasting of the Caspian Sea dynamics was carried out every ten days with horizontal resolution of $\sim 5 \mathrm{~km}$ on the basis of climatic information about water temperature and salinity and decade-averaged wind NCEPNCAR. Examples of calculations are presented here and their comparison with space

\section{of model validation are discussed.}

\section{Introduction}

Numerical modeling of the Black and Caspian seas' dynamics was fulfilled in the State Oceanographic Institute of Russian Federation (SOI) within the framework of the European ECOOP project (European COastal-shelf sea OPerational observing and forecasting system, 2007-2010 years) and the national project JISWO (Joint Information System on World Ocean). In both cases, a well-known numerical Princeton Ocean Model (POM,/1,5,6/), adapted for the regional conditions, was used.

The purpose of the paper is a description of the automated system of nowcasting and forecasting of hydrophysical parameters built during ECOOP and the estimation of quality of modeled fields. First of all, the system output in the Russian part of the Black Sea is described. These results were obtained in close co-operation with other participants of the project, particularly with the Marine Hydrophysical Institute of National Academy of Sciences of Ukraine, Sevastopol (MHI). The comparison of observations Sea are presented in this paper. This work represents the Russian Federation in a

OSD

$8,1865-1890,2011$

\section{Numerical modeling of dynamics of Russian south waters}

A. V. Grigoriev et al.

\section{Title Page}

Abstract

\section{Full Screen / Esc}

Printer-friendly Version

Interactive Discussion

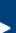

ose

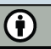


project and has been carried out for several years now. The continuation of the work is planned.

\section{Black Sea}

At the task of boundary conditions, nested grid technology (one-way nested grid borders of area were delivered by a basin-scale model of circulation of $\mathrm{MHI} / 2 /$.

Values of parameters in nodes of regional models were calculated first with the use of horizontal linear interpolation of the values in the adjacent nodes of a global grid, and then by means of splines using vertical interpolation. Total fluxes through the section 10 border in regional and global models strictly coincided, and components of baroclinic speeds of currents in regional models were equal to corresponding components of global baroclinic speeds. In boxes where water flowed into the settlement area, values of temperature and salinity were set. In points where water flowed out, the condition was used:

$15 \frac{\partial T}{\partial n}=\frac{\partial S}{\partial n}=0$

For the barotropic mode of normal component of barotropic speed on eastern and western borders, the following conditions were used:

$\bar{U}_{\mathrm{POM}}^{\text {normal }}=\bar{U}_{\mathrm{COARSE}}^{\text {normal }}+\varepsilon \sqrt{\frac{g}{H}}\left(\eta_{\mathrm{POM}}-\eta_{\mathrm{COARSE}}\right)$,

where $\varepsilon=1$ for the eastern border and $\varepsilon=-1$ for the southern border. The subscript 20 "coarse" specifies a large-scale model. For a tangent component of barotropic speed, the following conditions were used:

$\bar{U}_{\mathrm{POM}}^{\text {tang }}=\bar{U}_{\text {COARSE }}^{\text {tang }}$
OSD

$8,1865-1890,2011$

\section{Numerical modeling of dynamics of \\ Russian south waters}

A. V. Grigoriev et al.

\section{Title Page}

Abstract

Introduction

Conclusions

References

Tables

Figures

14

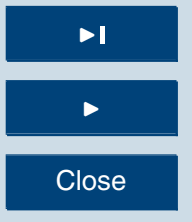

Back

Close

Full Screen / Esc

Printer-friendly Version

Interactive Discussion 
Horizontal resolution of regional model is $\sim 1 \mathrm{~km}$ at 18 vertical sigma-layers/1/), for $\mathrm{MHI}$ model $\sim 5 \mathrm{~km}$ (Table 1). The MHI model uses satellite data assimilation of altimetry and sea surface temperatures and also meteorological data (wind stress, flows of heat and mass) received from the National Meteorological Administration of Rumania within the 5 framework of the European cooperation (Fig. 1). The SOI receives the necessary border conditions for the regional Russian model in a daily mode from the $\mathrm{MHI}$ server and makes nowcasting and forecasting (for 3 days) calculations of thermohaline structures and water dynamics of the region. The initial data for the forecast is generated daily as a result of the MHI Black Sea Forecasting Operational System work (BSFOS).

10 Before the year 2009, calculations for the Black Sea were carried out in the test mode for debugging of technology. The results of the design were compared with the information of in-situ (CTD) and remote (SST) observations. An example of these results is shown in Fig. 2.

As seen in Fig. 2, the model reproduces both anticyclonic vortexes located on the 15 shelf-slope zone with a characteristic horizontal scale of $\sim 100 \mathrm{~km}\left(A z_{1}\right)$, and vortexes diagnosed according to the contact and satellite measurements eddies with a scale of $\sim 10 \mathrm{~km}\left(A z_{2}\right)$.

The process was fully automated in SOI and includes four stages (Fig. 3):

- receipt of initial information from the MHI ftp-server by internet;

- realization of model calculations;

- visualization of the results of calculations (temperature, salinity, current velocity, sea level);

- transmission of results to the SOI server and website and for use in the national JSIWO program (Fig. 4).

25 It is interesting to compare the results with the measured data, in situ and remote, to assess the quality of modeling of dynamics and the thermohaline structure of waters in that Black Sea region. Comparison of modeled results with in situ and remote data has 1868

\section{OSD}

$8,1865-1890,2011$

\section{Numerical modeling of dynamics of Russian south waters}

A. V. Grigoriev et al.

\section{Title Page}

\section{Full Screen / Esc}

Printer-friendly Version

Interactive Discussion 
been performed. Contact measurements (CTD) obtained by R/V Professor Shtokman of "Shirshov's" Institute of Oceanology (IO RAS) for the period of 9 March until 2 April 2009 were used. In Fig. 5, the regions of R/V Survey and modeling are shown.

It should be noted at the beginning that some characteristics of water in the region 5 in March should be reflected in the measurement data and modeling/7/. The vertical structure is an upper quasi-homogeneous layer (UQHL, several tens meters), thermohalo- pycnocline below to depths of $500 \mathrm{~m}$ and the underlying quasi-homogeneous layer. The main feature of the vertical structure of the waters of the Black Sea is the so-called cold intermediate layer (CIL) with the axis at depths of 50-100 m depending 10 on the point of observation. Rim Current has extending along the continental slope, roughly along the isobath $1200 \mathrm{~m}$, and produces a general cyclonic circulation in the sea. In the area of the continental slope, the eddies with spatial scales of $\sim 100 \mathrm{~km}$ are also observed, and directly in the shelf-slope zone - anticyclonic eddies with horizontal dimensions are about $10 \mathrm{~km}$ (see Fig. 2). These dynamic characteristics are reflected

the salinity is a major contributor to the spatial distribution of the density of Black Sea water, determining its dynamics. Therefore, profiles, sections and maps are constructed from the values of salinity, the most informative in analyzing the features of water dynamics in the region.

Vertical profiles built both from CTD and modeled data reflect the typical vertical ticular, the presence of the upper quasi-homogeneous layer (UQHL) with a capacity ticular, the presence of the upper quasi-homogeneous layer (UQHL) with a capacity of $\sim 40 \mathrm{~m}$, the cold intermediate layer (CIL) with the axis at a depth of $60 \mathrm{~m}$, the main pycnocline to depths of $500 \mathrm{~m}$ and the underlying quasi-homogeneous layer. The vertical profiles of salinity and density are of the same type because the water density in Black Sea is mostly defined by salinity. Qualitatively, the model and the observed profiles are very similar. For the salinity difference in values of the order of $\sim 0.1 \%$, for the temperature there is the same order in degrees ${ }^{\circ} \mathrm{C}$ at depth. A maximum difference in temperatures is observed on a surface - approximately $1.5^{\circ} \mathrm{C}$.

\section{OSD}

$8,1865-1890,2011$

\section{Numerical modeling of dynamics of Russian south waters}

A. V. Grigoriev et al.

\section{Title Page}


Distribution of thermohaline characteristics at a cross-section perpendicular to the coast (see Fig. 5) is typical for the Black Sea, and shows a decline in the depth of isolines from coast to the center of the sea, caused by a general cyclonic circulation (Fig. 7). The section shown in Fig. 7a is built from asynchronous CTD-data made by 5 R/V Professor Shtokman in the period 10/03/2009-13/03/2009. Figure 7b is built from model data corresponding to the points and times of ship observations. Comparing Fig. $7 \mathrm{a}$ and $\mathrm{b}$, we can conclude that the salinity distribution in sections are similar and have similar quantitative values. As the differences can be noted, large vertical salinity gradients in halocline on the cross-section, which was built from CTD-data. But re10 ducing the spatial discreteness of the model data in the cross-section is well defined deflection contour lines in the shelf-slope (right side of Fig. 7c) due to the presence of the anticyclonic vortex with the spatial size of $\sim 10 \mathrm{~km}$ (see Fig. 8a). A similar distribution of isolines on the edge of the continental slope of Black Sea is fixed often from CTD data of many hydrological surveys with a small horizontal step $(\sim 1 \mathrm{~km})$.

15 Synoptic variability in space and time is clearly expressed in the model calculations of water dynamics in the region. As an example, the model velocity fields corresponding to the beginning and end of the hydrological survey R/V Professor Shtokman is shown in Fig. 8. With regard to estimates of the degree of differences of model and measured values, then, due to high degree of asynchrony of the hydrological survey, comparison between measured and modeled data does not make any sense. Therefore, the estimations of quality of modeling are possible using remote sensing. Examples of comparisons of modeled data with satellite observations are shown in Figs. 8, 9. Thus, synoptic eddies, reflected in the salinity field (model) and the concentration of chlorophyll A (satellite image) show a high correspondence in the spatial size and horizontal location (Fig. 9). The RMS of the difference between the model and the measured (Sea Surface Temperature, SST) temperature in area of modeling for 2 July, 2009, was equal to $\mathrm{RMS}=1.1^{\circ} \mathrm{C}$ (Fig. 10).

\section{OSD}

8, 1865-1890, 2011

\section{Numerical modeling of dynamics of Russian south waters}

A. V. Grigoriev et al.

\section{Title Page}

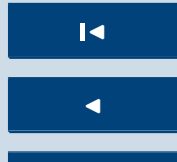

\section{Full Screen / Esc}

Printer-friendly Version

Interactive Discussion 
As seen in the figures presented, some shift of location of $T, S$ anomalies in modeled calculations concerning supervision takes place. For elimination of this effect, data assimilation in a local model can be used (now it can only be assimilated in a basinscale model).

5 It is also interesting to analyze how the magnitude of the errors of forecasting (Fig. 11) is dependent on the time of forecasting. This is done using the information about temperature and salinity at the moments of contact measurements (for Station 5). For temperature, the minimum number of errors takes place in the case of 1-2 days forecasting (except the depths below CIL, where variability is considerably low 10 than within UQHL). In the upper layers, the forecasting is closer to measurements then nowcasting ( 0 days in the Fig. 11). It is worth mentioning the considerable errors of modeled temperature in the upper layer. (As the research of colleagues from MHI showed, this failing can be decreased by the division of the heat flow on the surface of the sea into long-wave and short-wave parts.) For salinity, the maximum of errors is located in the range of depths about 100-200 m (main halo- pycnocline). In the upper layers, the presence of local maximum of errors when forecasting for 2 days is distinct. But in general, a forecasting for 1 day (and at some depths for 3 days) does not yield or excels nowcasting in quality.

The reasons for such results could be following:

- Nowcasting during the Project was carried out by the model for the time span of 1 day. Possibly, this time is not enough and it is necessary to increase it up to 2 days.

- In addition, dynamic features of interaction between the currents and bottom relief and adaptation with the wind stress likely show up during the forecast, which finds
OSD

$8,1865-1890,2011$

\section{Numerical modeling of dynamics of Russian south waters}

A. V. Grigoriev et al.

\section{Title Page}

Abstract

Introduction

Conclusions

References

Tables

Figures

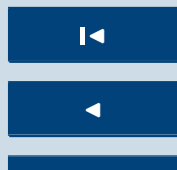

$\Delta$

Back

Close

Full Screen / Esc

Printer-friendly Version

Interactive Discussion 


\section{Caspian Sea}

The formal parameters of the numerical model were the following: the grid for calculation which covered the total water area of the sea had the dimensions $243 \times 193 \times 18$ points and lay in borders of $36.6^{\circ}-47.0^{\circ}$ northern latitude and $47.0^{\circ}-54.0^{\circ}$ east lon-

5 gitude. The grid step was equal to $4.9 \mathrm{~km}$ in latitude and $3.7 \mathrm{~km}$ in longitude. The levels were thickening exponentially from the middle layers to the surface and to the bottom of the sea for the best resolution of the surface and bottom border layers. Initial temperature and salinity fields were climatic $/ 3 /$, and have been time interpolated for every decade of the months. The data of NCEP/NCAR reanalysis was used for 10 a daily pressure field over the Caspian Sea (http://www.cdc.noaa.gov/cdc/reanalysis/ reanalysis.shtml), which was interpolated by means of splines on the chosen spatial grid. The wind stress fields were calculated according to the data about atmospheric pressure. Along with temperature and salinity fields, the wind stress fields are used as input data and are sufficient for every decade nowcasting calculations of the current 15 fields in the Caspian Sea.

As well as for the Black Sea, the process includes several stages which have been completely automated. The stages are:

1. information read-out of atmospheric pressure over the Caspian Sea;

2. the calculation of the average decade fields of atmospheric pressure;

3. the calculation of the average decade wind stress according to the data about atmospheric pressure;

4. the placement of the files of initial (temperature, salinity) and boundary (wind stress) conditions in folders corresponding to each decade of the month;

\section{Numerical modeling of dynamics of Russian south waters}

A. V. Grigoriev et al.

\section{Title Page}

\section{Full Screen / Esc}

Printer-friendly Version

5. realization of model calculations;

Interactive Discussion 
The results of calculations - the current velocity fields, - are transferred to the SOI server in a numerical and graphic form every decade for their use in JISWO project (Fig. 12).

5 Besides regular (every decade) calculations of the current fields in the Caspian Sea, that are intended to be used in problems of operation oceanography, it is of interest to estimate the volatility of energy characteristics and their spectra according to the modeling calculations for the long-term period. Such estimations are of interest, both to the detection of within year regularity of processes in the sea and to the verification of the physical adequacy of modeling. These estimations have been made according to the data about every decade calculations that have been executed within 2008-2009. Some of the results are given in Figs. 13 and 14.

The autumn-winter maxima are expressed in the time dependence of kinetic energy (Fig. 13). Apparently, they are caused by the generated top uniform layer that is the 15 consequence of the autumn-winter convection and also of the winter intensification of wind circulation that is typical for the seas of middle latitudes. On the surface the process of a seasonal intensification of circulation is shifted to the autumn. This indicates that the factors defining the intensification first of all influence the surface layer, and with the lapse of time, extend the influence onto deeper layers. The spectral analysis of series of volatility of circulation shows that local maxima correspond to frequencies of $\sim 10$ days, $\sim 1$ and $\sim 3$ months (Fig. 14), thus corresponding to synoptic processes (10 days), mesoscale (1 month), connected with the restructuring of thermohaline structure of water, and seasonal (3 months). The spectral characteristics of the variability of kinetic energy, calculated according to the results of numerical modeling, are physically adequate and internally consistent. This confirms the correctness of the calculations and of the results received.

\section{OSD}

$8,1865-1890,2011$

\section{Numerical modeling of dynamics of Russian south waters}

A. V. Grigoriev et al.

\section{Title Page}

Abstract
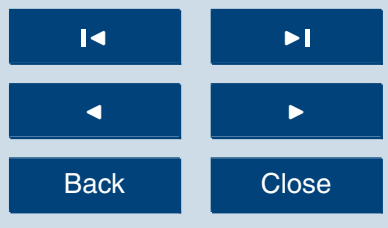

Full Screen / Esc

Printer-friendly Version

Interactive Discussion 


\section{Conclusions}

During the Project, an automated system of modeling the dynamics of water of the Black Sea and the Caspian Sea was created. It allows generation of physically adequate results of calculations of thermohaline structure of water and current fields. For 5 the Black Sea such calculations are performed in nowcasting and forecasting (3 days) mode, while for the Caspian Sea the calculations are performed in the decade mode of nowcasting of current fields.

In addition to a satisfactory qualitative and quantitative agreement between the model data, CTD and remote measurements of the dynamics and water structure in the

Russian Black Sea area, another result is important. On the basis of this experiment,the conclusion that the proposed modeling technology can adequately monitor the variability of the waters of the region with the spatial and temporal resolution, unattainable using only field data, can prove important for operational oceanography.

\section{References}

15 Blumberg, A. F. and Mellor, G. L.: A description of a three-dimensional coastal ocean model. in Three Dimensional Shelf Models, Coast. Estuar. Sci., Vol. 5, edited by: Heaps, N., 1-16, AGU, Washington, D.C., 1987.

Dorofeev, V. L. and Korotaev, G. K.: Assimilation of satellite altimetry data in eddy-resolving circulation model of the Black Sea, Marine Hydrophysical J., 1, 52-68, 2004. (in Russian)

20 Kosarev, A. N. and Tuzhilkin, V. S.: Climatic thermohaline fields of the Caspian Sea. Moscow, SORBIS, p. 96, 1995. (in Russian)

Kubryakov, A., Grigoriev, A., Kordzadze, A., Stefanescu, S., Trukhchev, D., and Korotaev, G.: Nowcasting subsystem of the circulation in the Black Sea nearshore regions - 4-th EuroGOOS Conference, European Operational Oceanography: Present and Future, Abstracts,

Mellor, G. L.: User's guide for a three dimensional, primitive equation, numerical ocean model, report, Program in Atmos. and Ocean. Sci., Princeton Univ., Princeton, 3 , 35 pp., 1991.

\section{Numerical modeling of dynamics of Russian south waters}

A. V. Grigoriev et al.

\section{Title Page}

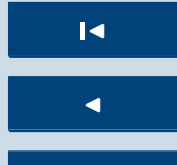

\section{Full Screen / Esc}

Printer-friendly Version

Interactive Discussion 
Mellor, G. L. and Yamada, T.: Development of turbulence closure model for geophysical fluid problems, Rev. Geophys., 20, 851-875, 1982a.

Zatsepin, A. G., Ginzburg, A. I., Kostianoy, A. G., Kremenetskiy, V. V., Krivosheya, V. G., Stanichny, S. V., and Poulain, P.-M.: Observations of Black Sea mesoscale eddies and associated horizontal mixing, J. Geophys. Res., 108, C8, doi:10.1029/2002JC001390, 2003.

OSD

$8,1865-1890,2011$

Numerical modeling of dynamics of

Russian south waters

A. V. Grigoriev et al.

\section{Title Page}

Abstract

Introduction

Conclusions

References

Tables

Figures

14

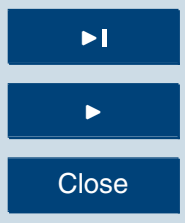

Back

Close

Full Screen / Esc

Printer-friendly Version

Interactive Discussion

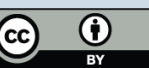


Table 1. Main features of global and regional models

\begin{tabular}{|c|c|c|c|c|c|}
\hline $\begin{array}{l}\text { Main features } \\
\text { of models }\end{array}$ & Type & $\begin{array}{l}\text { Vertical } \\
\text { coordinates }\end{array}$ & Grid size & $\begin{array}{l}\text { Number of } \\
\text { grid points }\end{array}$ & Time step \\
\hline $\begin{array}{l}\text { Basin scale } \\
\text { model (MHI) }\end{array}$ & $\begin{array}{l}\text { MHI-model with } \\
\text { remote sensing } \\
\text { data assimilation }\end{array}$ & $\begin{array}{l}\text { Fixed levels in } \\
\text { the vertical } \\
\text { z-direction }\end{array}$ & 4900 m & $237 \times 131 \times 35$ & $600 s$ \\
\hline $\begin{array}{l}\text { Northeastern Russian } \\
\text { Coastal Zone Regional } \\
\text { Model }\end{array}$ & $\begin{array}{l}\text { POM-model } \\
\sigma \text {-coordinates }\end{array}$ & Terrain following & $\sim 1000 \mathrm{~m}$ & $304 \times 254 \times 18$ & $\begin{array}{l}120 \mathrm{~s} \\
\text { (baroclinic mode) } \\
3 \mathrm{~s} \\
\text { (barotropic mode) }\end{array}$ \\
\hline
\end{tabular}

\section{OSD}

8, 1865-1890, 2011

\section{Numerical modeling of dynamics of \\ Russian south waters}

A. V. Grigoriev et al.

\section{Title Page}

\section{Abstract}

Introduction

Conclusions

References

Tables

Figures

14

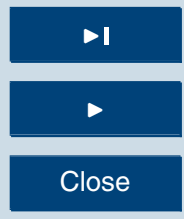

Back

Close

Full Screen / Esc

Printer-friendly Version

Interactive Discussion 


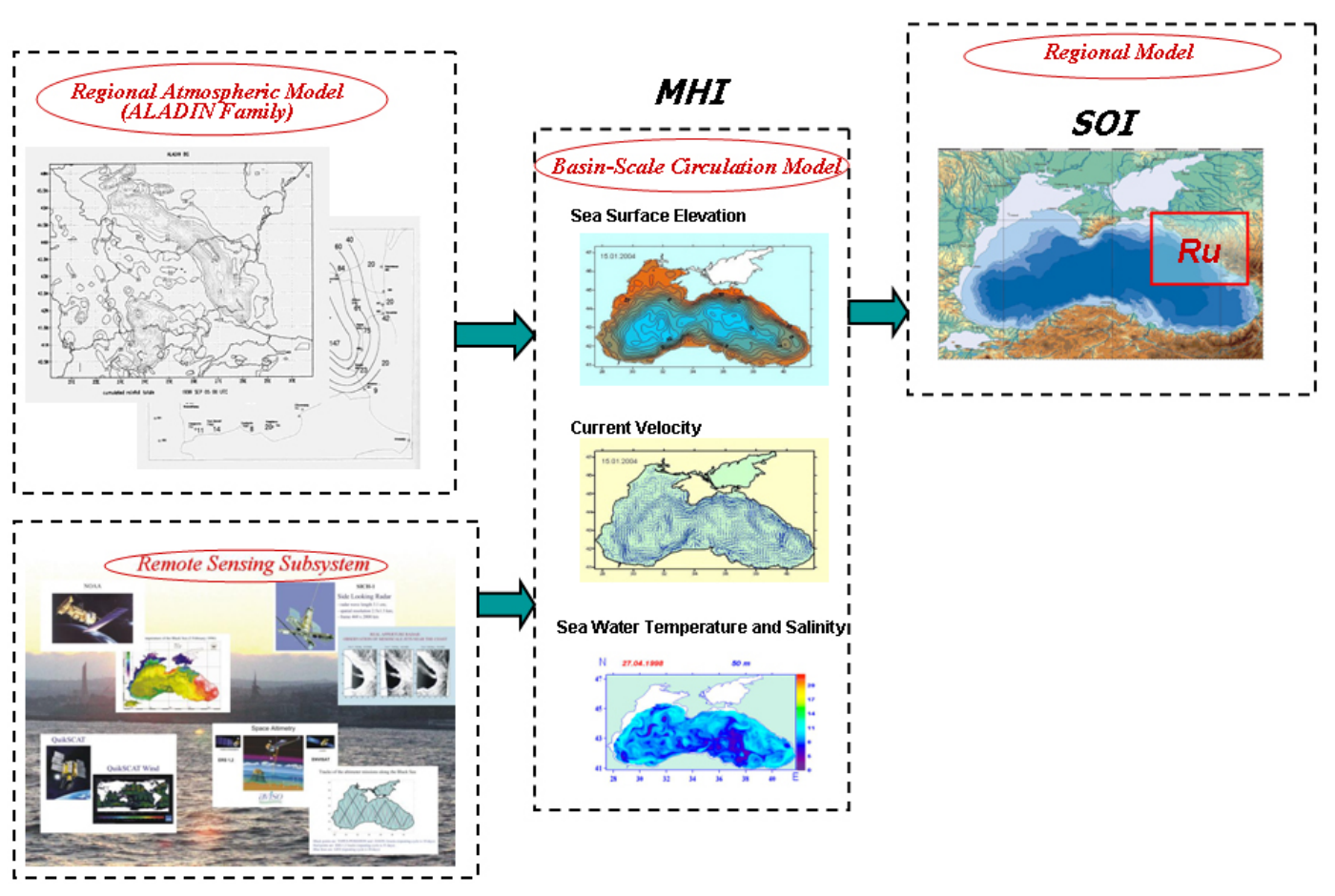

Fig. 1. System of nowcasting and forecasting of Black Sea water dynamics.

OSD

8, 1865-1890, 2011

\section{Numerical modeling of dynamics of \\ Russian south waters}

A. V. Grigoriev et al.

\section{Title Page}

\section{Abstract}

Introduction

Conclusions

References

Tables

Figures
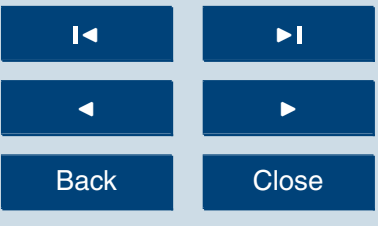

Full Screen / Esc

Printer-friendly Version

Interactive Discussion 


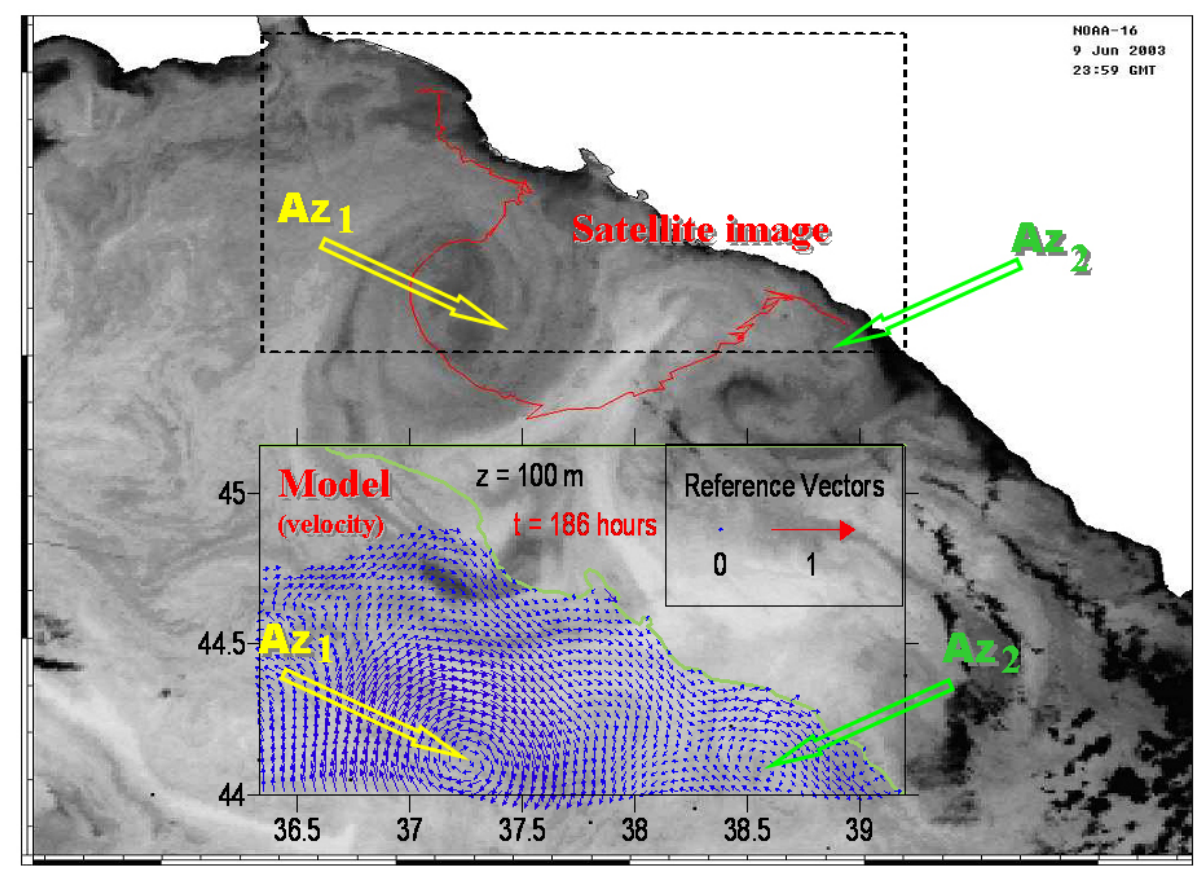

\section{OSD}

8, 1865-1890, 2011

\section{Numerical modeling of dynamics of}

\section{Russian south waters}

A. V. Grigoriev et al.

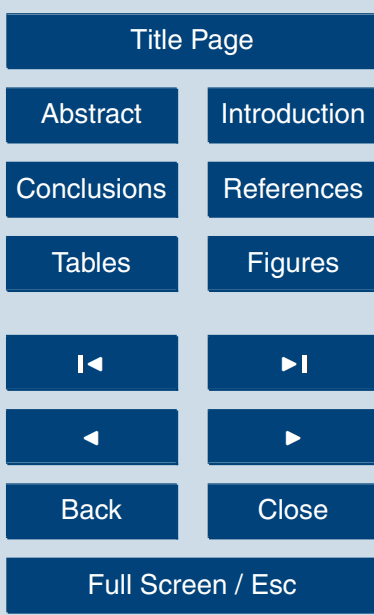

Fig. 2. Comparison of the modeled results (currents) with satellite image. 


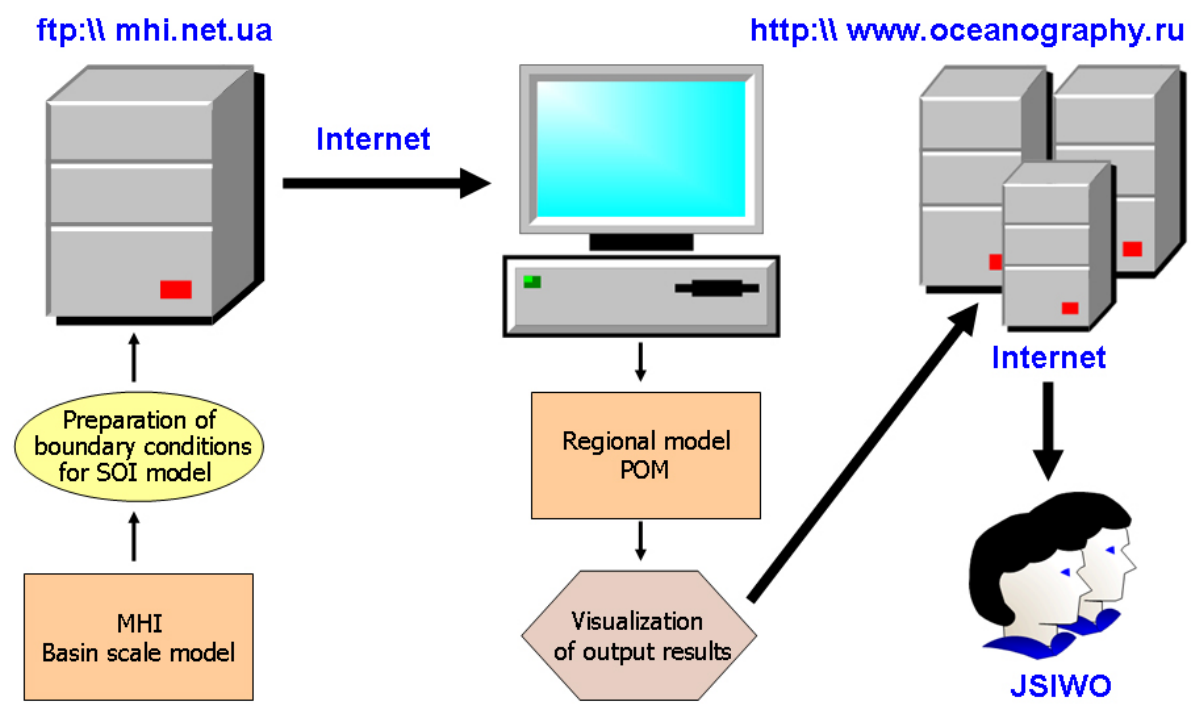

OSD

8, 1865-1890, 2011

\section{Numerical modeling of dynamics of}

Russian south waters

A. V. Grigoriev et al.

\section{Title Page}

\section{Abstract}

Introduction

Conclusions

References

Tables

Figures
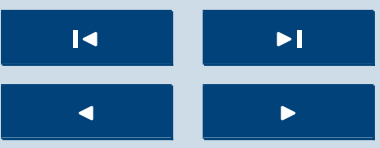

Back

Close

Fig. 3. Scheme of SOI automated system.

Full Screen / Esc

Printer-friendly Version

Interactive Discussion 


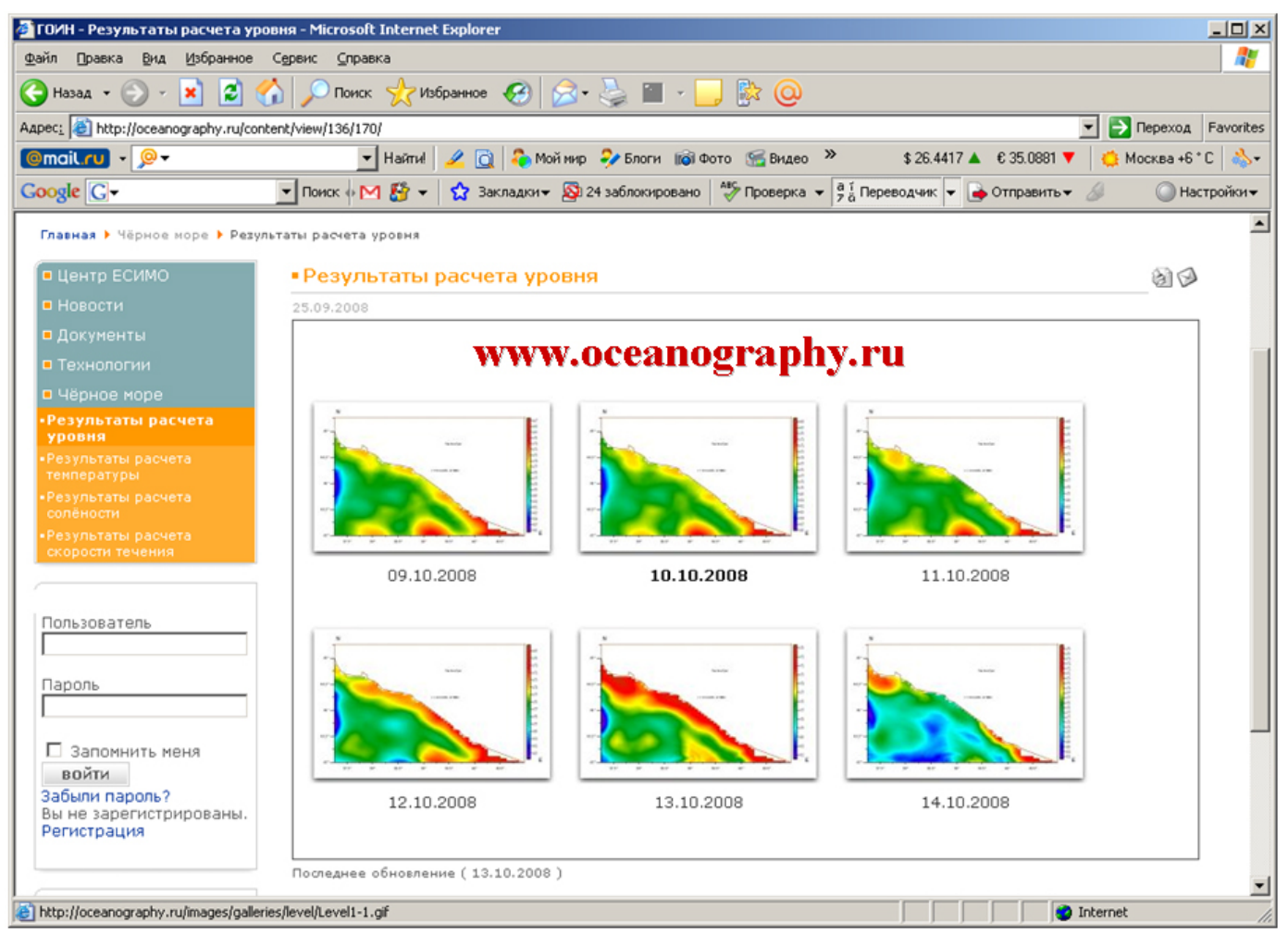

Fig. 4. Example of modeled results shown on the SOI website.

\section{OSD}

8, 1865-1890, 2011

\section{Numerical modeling of dynamics of}

\section{Russian south waters}

A. V. Grigoriev et al.

\section{Title Page}

Abstract

Introduction

Conclusions

References

Tables

Figures

14

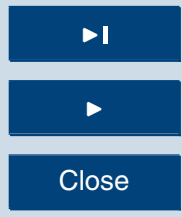

Back

Close

Full Screen / Esc

Printer-friendly Version

Interactive Discussion 


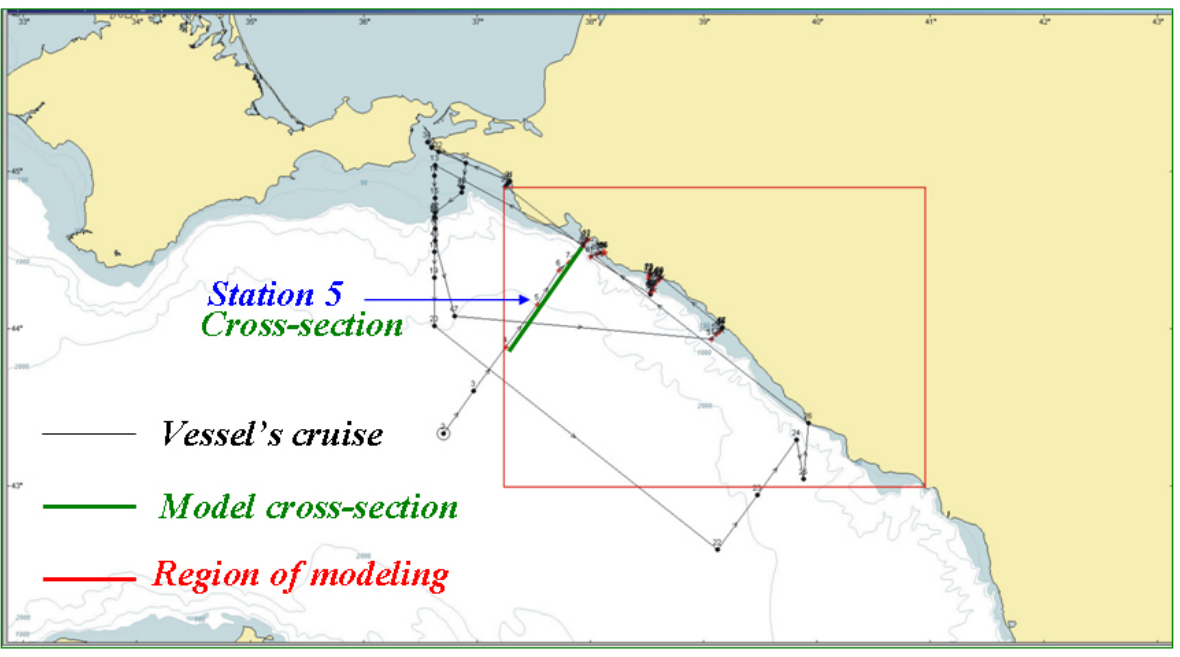

OSD

$8,1865-1890,2011$

\section{Numerical modeling of dynamics of}

Russian south waters

A. V. Grigoriev et al.

\section{Title Page}

\section{Abstract}

Introduction

Conclusions

References

Tables

Figures

14

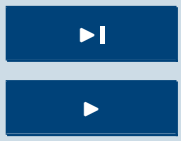

Back

Close

Fig. 5. Region of R/V Professor Shtokman survey and modeling area.

Printer-friendly Version

Interactive Discussion 


\section{OSD}

$8,1865-1890,2011$

\section{Numerical modeling of dynamics of \\ Russian south waters}

A. V. Grigoriev et al.
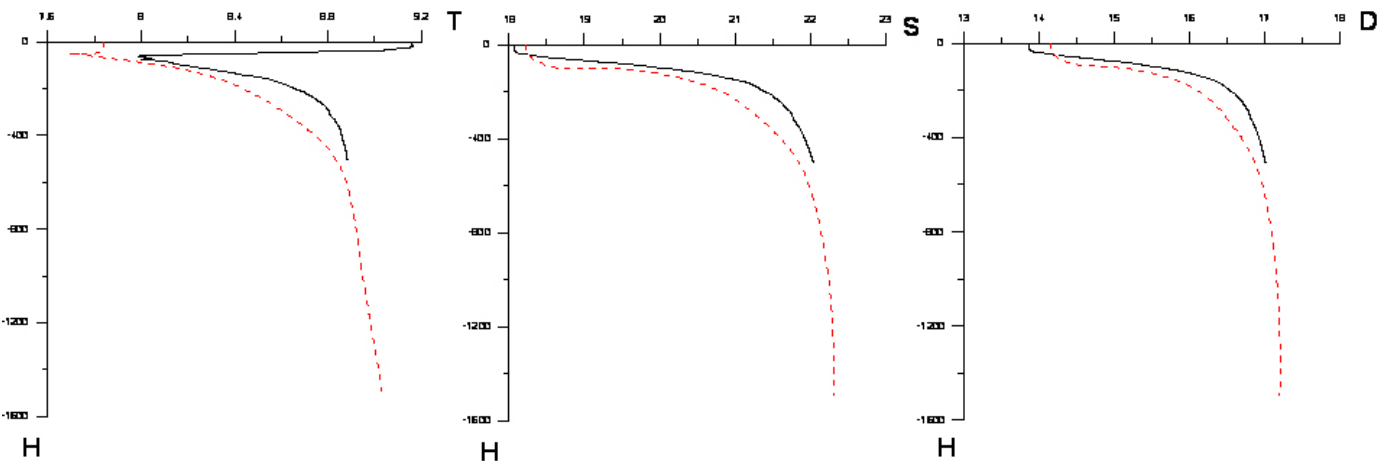

Fig. 6. Vertical profiles of temperature $(T)$, salinity $(S)$ and density $(D)$ for Station No. 5 from CTD data (black) and modeling (red).

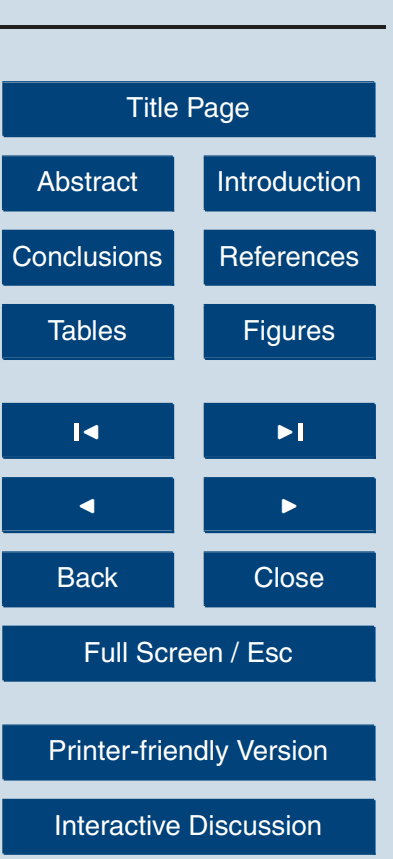


(a)
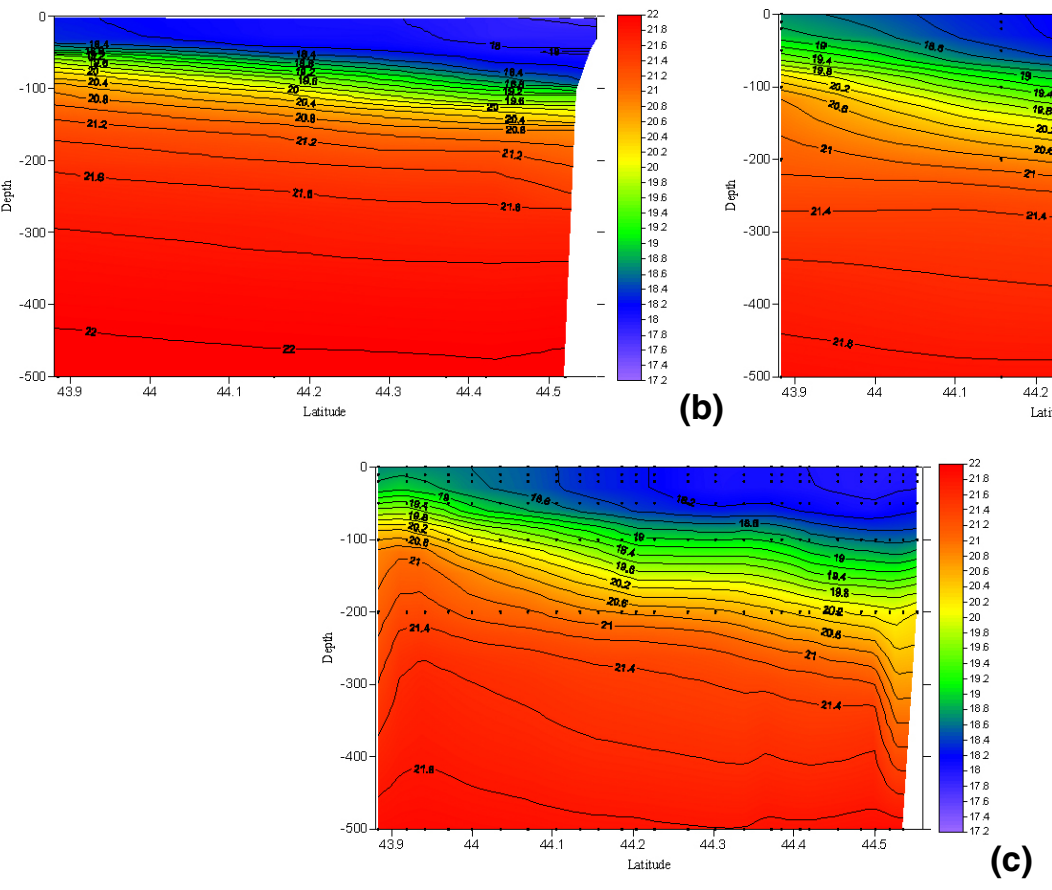

Fig. 7. Distribution of salinity on a cross-section (see the Fig. 5), obtained from CTD data (a) and model data (b, c).

\section{OSD}

8, 1865-1890, 2011

\section{Numerical modeling of dynamics of}

\section{Russian south waters}

A. V. Grigoriev et al.

\section{Title Page}

Abstract

Introduction

Conclusions

References

Tables

Figures
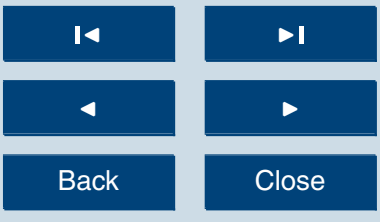

Full Screen / Esc

Printer-friendly Version

Interactive Discussion 


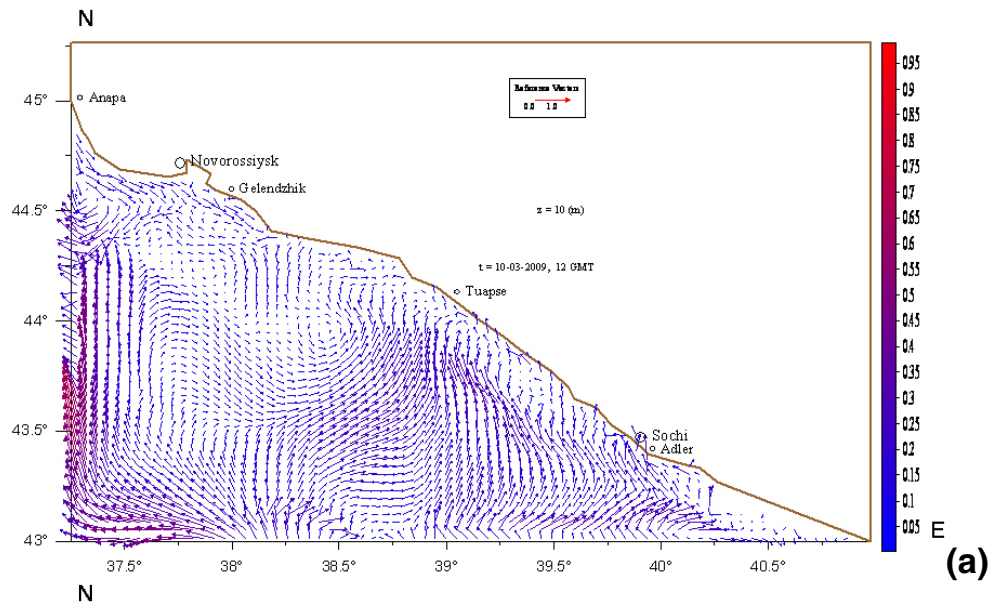

OSD

$8,1865-1890,2011$

\section{Numerical modeling of dynamics of}

\section{Russian south waters}

A. V. Grigoriev et al.

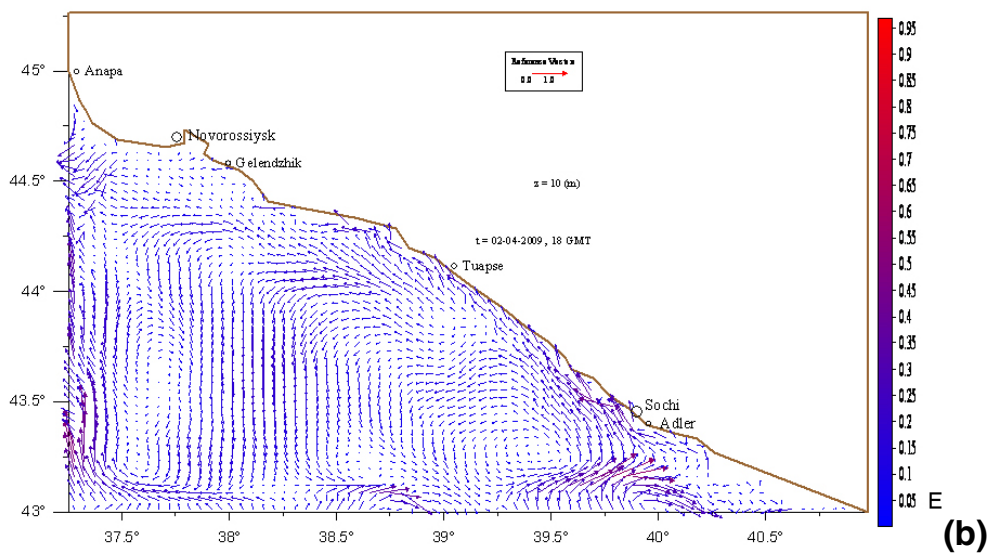

Title Page

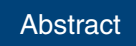

Introduction

Conclusions

References

Tables

Figures
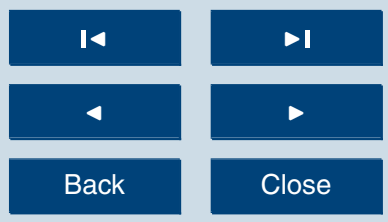

Full Screen / Esc

Printer-friendly Version

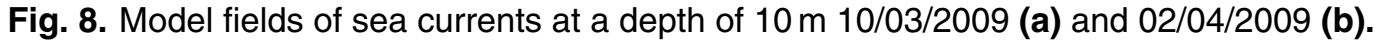

Interactive Discussion

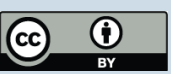




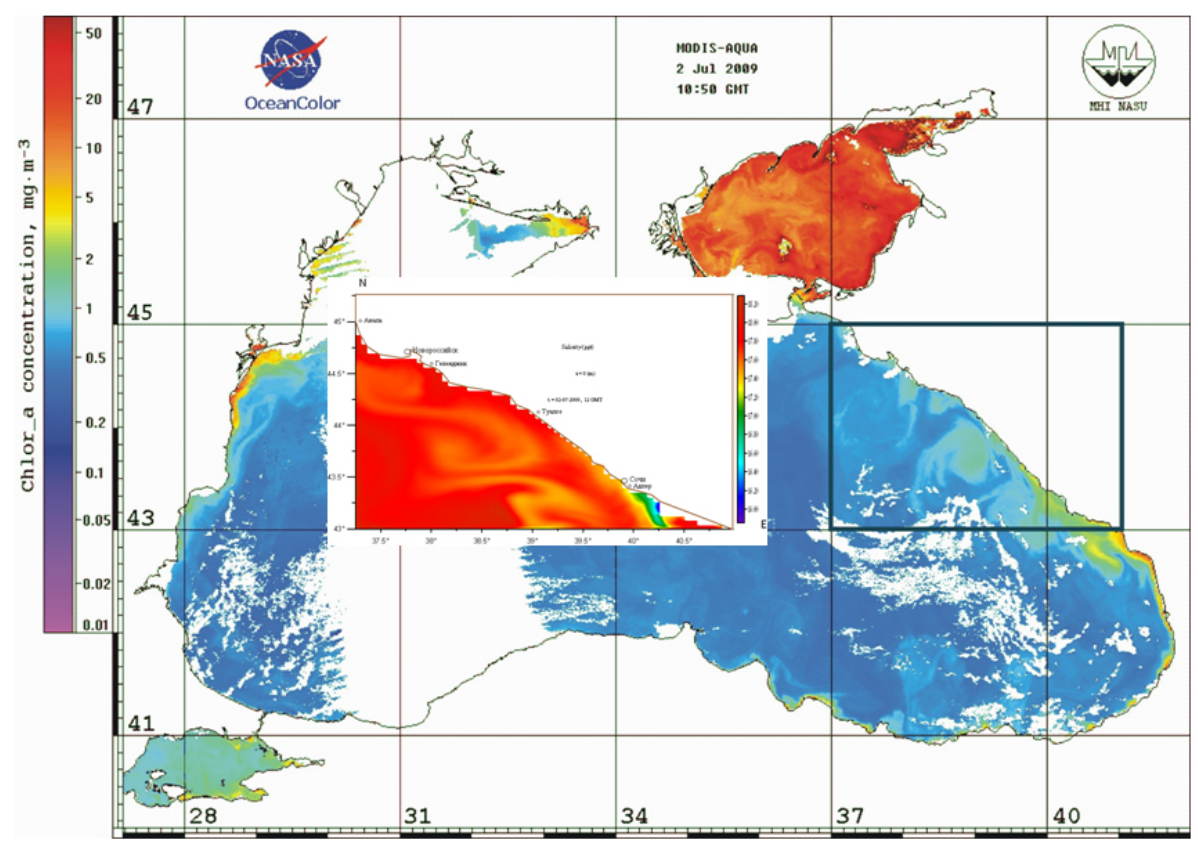

Fig. 9. Satellite image (Chlorophyll concentration) and modeled sea surface salinity at 2 July, 2009.

\section{OSD}

$8,1865-1890,2011$

\section{Numerical modeling of dynamics of}

\section{Russian south waters}

A. V. Grigoriev et al.

\section{Title Page}

\section{Abstract}

Introduction

Conclusions

References

Tables

Figures
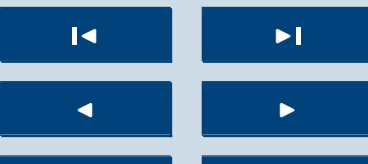

Back

Close

\section{Full Screen / Esc}

Printer-friendly Version

Interactive Discussion

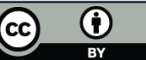




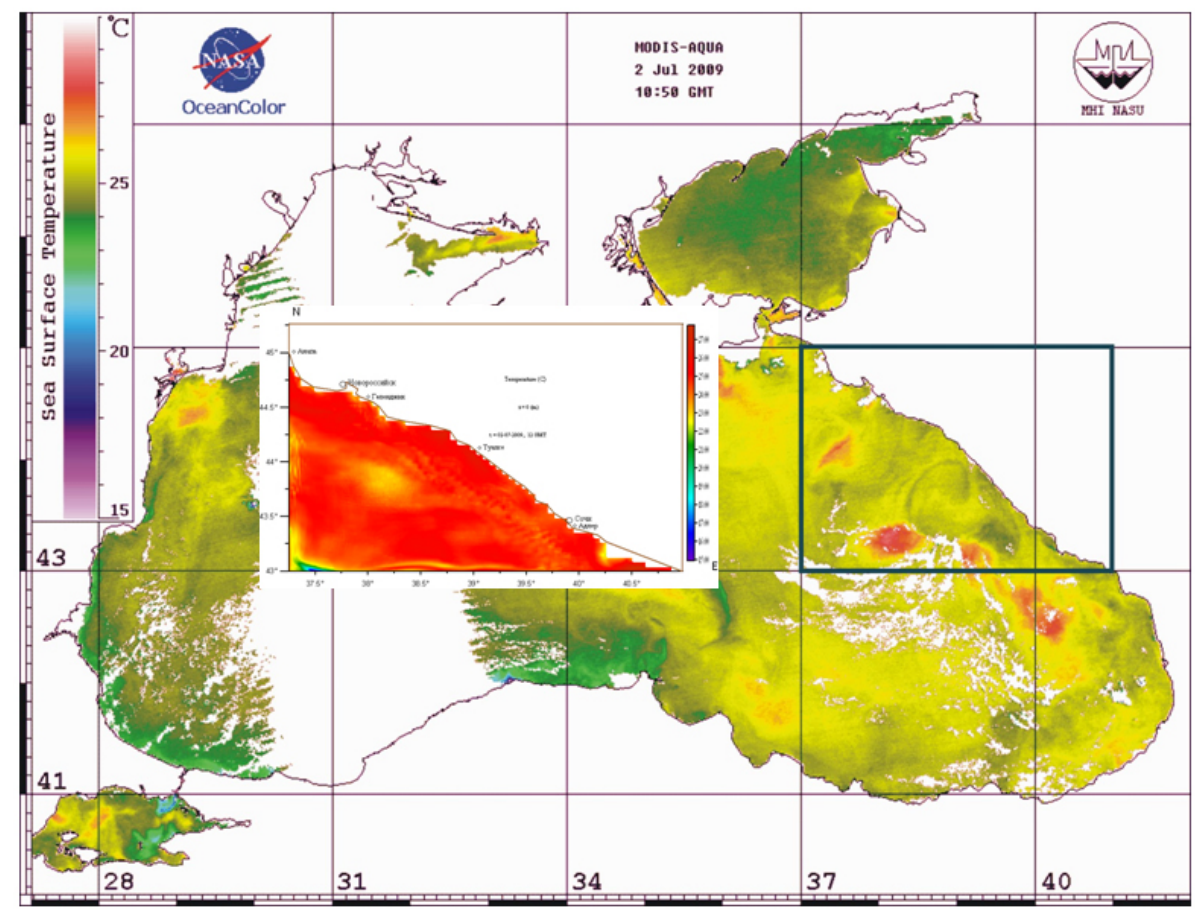

OSD

$8,1865-1890,2011$

\section{Numerical modeling of dynamics of}

\section{Russian south waters}

A. V. Grigoriev et al.

\section{Title Page}

Abstract

Introduction

Conclusions

References

Tables

Figures
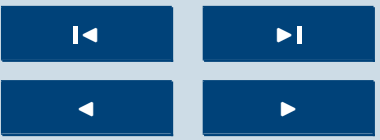

Back

Close

Full Screen / Esc

Fig. 10. Satellite image (SST) and modeled sea surface temperature at 2 July, 2009.

Interactive Discussion

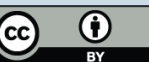




\section{OSD}

8, 1865-1890, 2011

\section{Numerical modeling of dynamics of \\ Russian south waters}

A. V. Grigoriev et al.
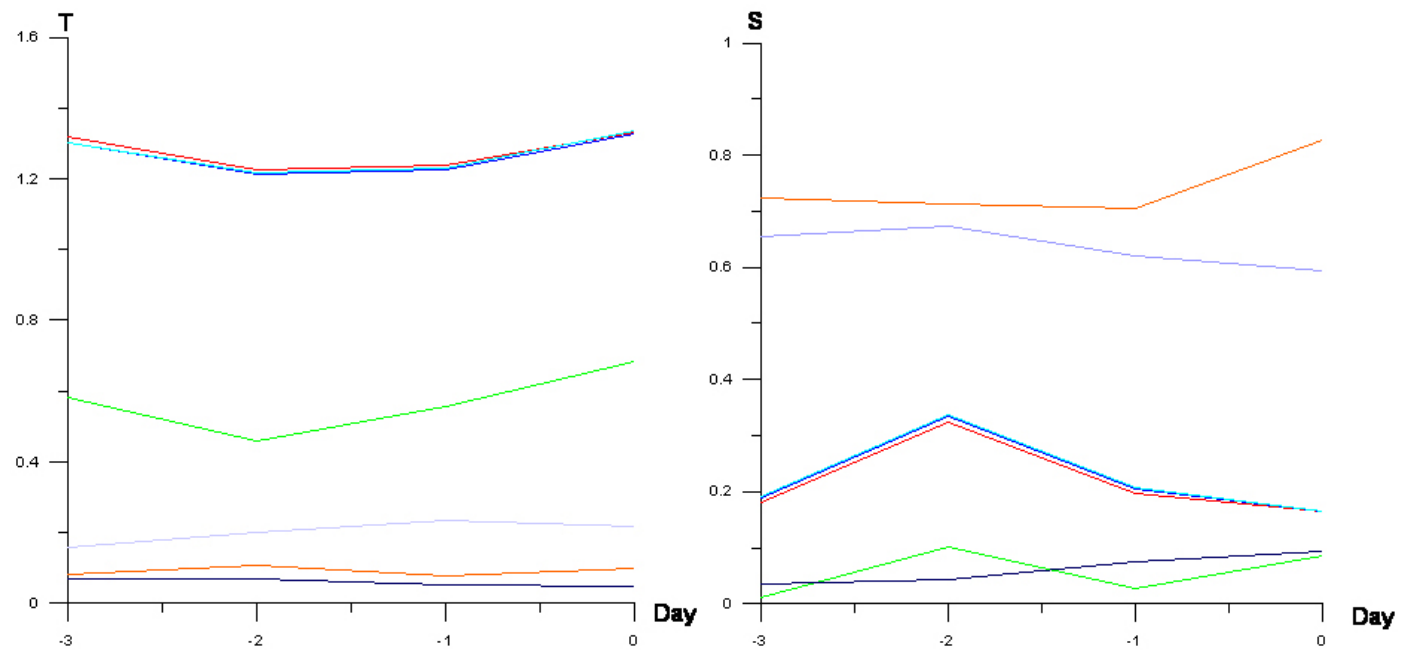

Title Page

\section{Abstract}

Introduction

Conclusions

References

Tables

Figures

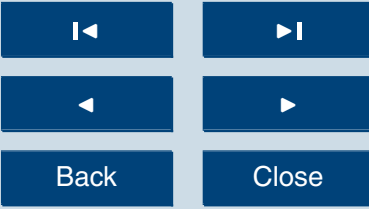

Full Screen / Esc

Fig. 11. Differences (absolute value) between measured and modeled temperature (a) and salinity (b) as a function of time of forecasting (1-3 days, 0 is nowcasting). Station 5 .
Printer-friendly Version

Interactive Discussion 


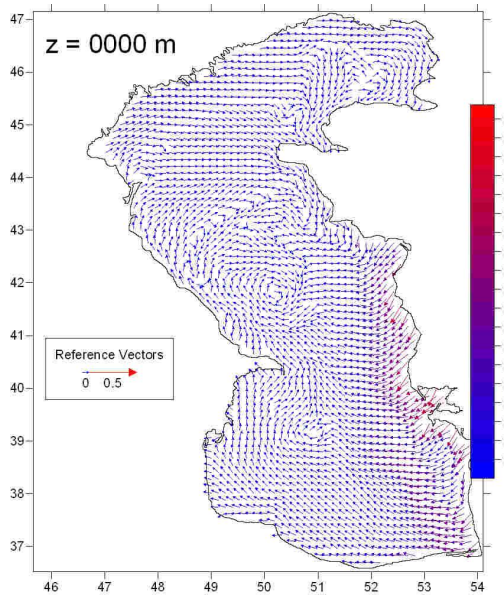

a) Current velocity at depth of $0 \mathrm{~m}$

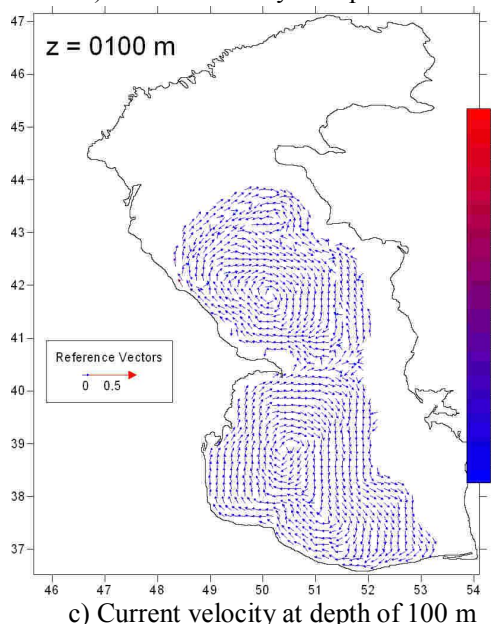

c) Current velocity at depth of $100 \mathrm{~m}$

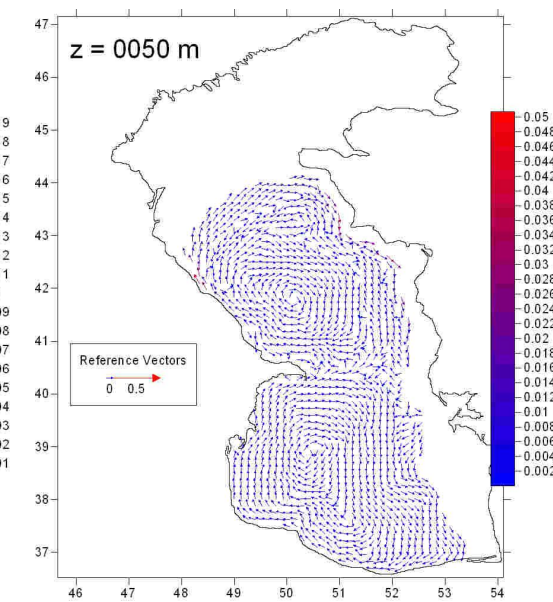

b) Current velocity at depth of $50 \mathrm{~m}$

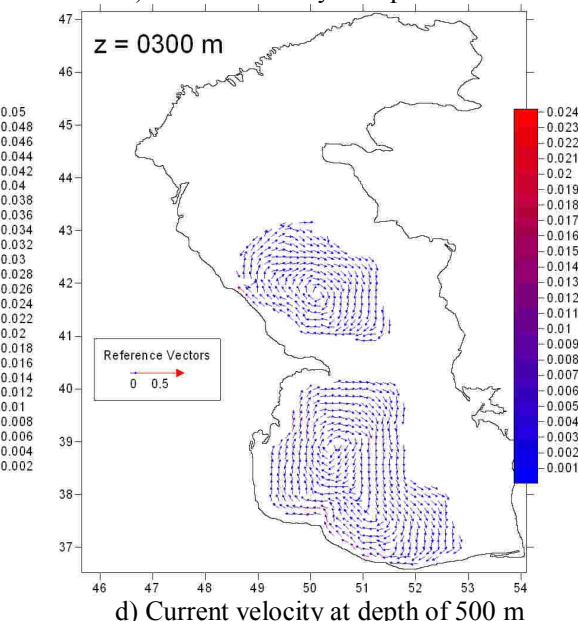

OSD

8, 1865-1890, 2011

Numerical modeling of dynamics of

\section{Russian south waters}

A. V. Grigoriev et al.

\section{Title Page}

Abstract

Introduction

Conclusions

References

Tables

Figures

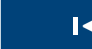

14

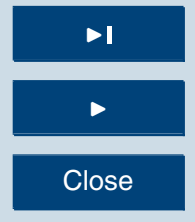

Back

Full Screen / Esc

Printer-friendly Version

Interactive Discussion

Fig. 12. Examples of the calculated fields of current velocity at horizons 0 (a), 50 (b), 100 (c) and 300 (d) meters. 


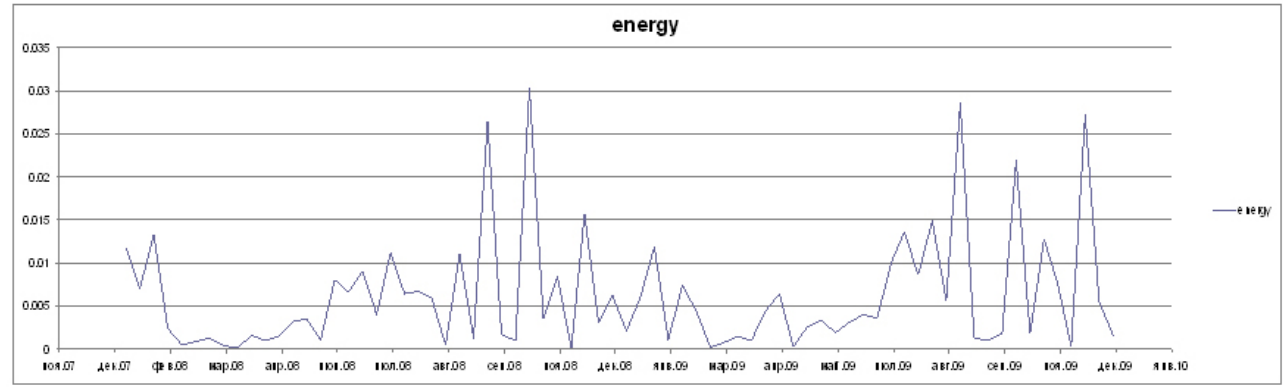

\section{OSD}

8, 1865-1890, 2011

\section{Numerical modeling of dynamics of \\ Russian south waters}

A. V. Grigoriev et al.

\section{Title Page}

Abstract

Introduction

Conclusions

References

Tables

Figures

Fig. 13. Average kinetic energy of currents for depth $0 \mathrm{~m}$. 


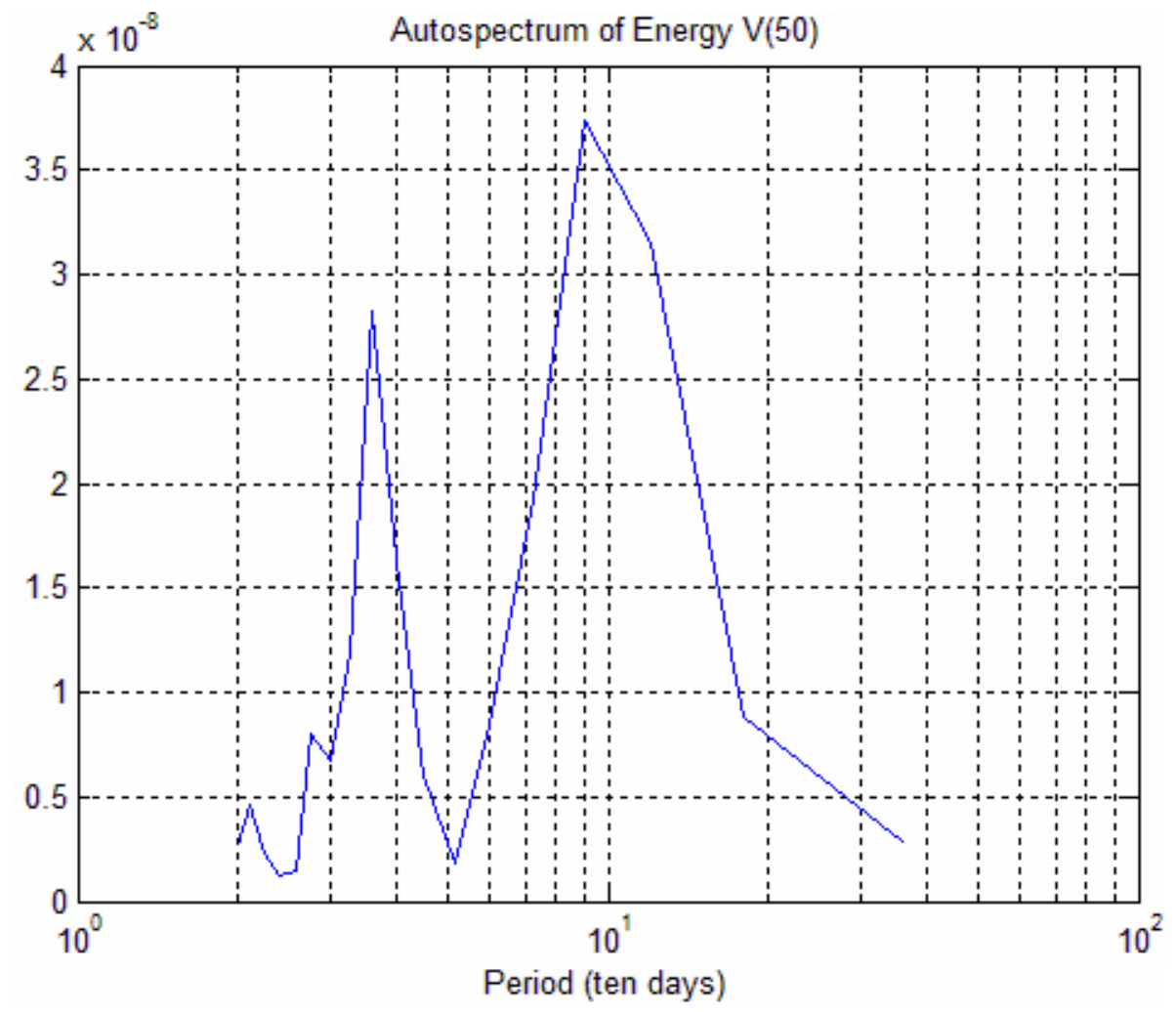

OSD

8, 1865-1890, 2011

\section{Numerical modeling of dynamics of}

\section{Russian south waters}

A. V. Grigoriev et al.

\section{Title Page}

\section{Abstract}

Conclusions

Tables

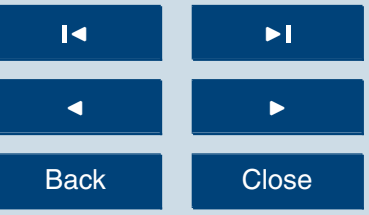

Full Screen / Esc

Printer-friendly Version

Interactive Discussion 